Др Миомира Костић,

Редовни професор Правног факултета,

Универзитет у Нишу
ОРИГИНАЛАН НАУЧНИ ЧЛАНАК

UDK: 343.9-052-053.9

Рад примљен: 17.09.2014.

Рад прихваћен: 21.10.2014.

\title{
СТАРИЈИ ОСУЂЕНИЦИ
}

Ancтракт: У криминолошкој литератури се износи јасан став да је криминалитет старијих унепосредној вези сњиховим ступањемунови период живота. Код старијих делинквената могуће је уочити образац у развоју делинквентне активности, структуру криминалитета, полну заступљеност делинквентних лища, претходно кажњавање, друштвени статус остарелих делинквената. Криминолошка истраживања старијих била су најчешће у домену испитивања страха од криминалитета, њихове виктимизације у оквиру породище, док је њихова делинквенција много ређе била предмет изучавања. Изучавање делинквенције старијих најчешће је било у значењу потреба и тешкоћа с којима је суочена затворска популација у трећем добу, када су изречене дугогодишње затворске казне, а правила условног отпуста остају строга, или када се критикује мањак посебних социјално прилагођених пенитенцијарних установа за остареле осуђенике. Ниво криминалитета опада с повећањем година старости. За разлику од константног пораста удела старог становништва у односу на млађе становништво у развијеним земљама света, удео осуђеничке популације, међу особама од 55 година живота и старијих, у односу на млађе осуђенике, ипак је знатно мањи. Наиме, различита питања која се односе на „старе особе иза решетака" постала су, временом, предмет интересовања, криминолога и пенолога, државне администрације, и међународних организација које се залажу за примену људских права. Утамничени мушкарци и жене уобичајено пате од физичких и психичких потешкоћа које карактеришу особе на слободи, али бар десетак година старије. Насиље, анксиозност, стрес у затворским условима, одвојеност од породице и пријатеља, као и спознаја могућности да ће сав или скоро сав остатак живота провести иза решетака, све заједно могу довести до убрзаног прощеса старења код осуђених лица.

Кључне речи: старост, старији осуђеници, делинквенција старијих, третман старијих.

*kosticm@prafak.ni.ac.rs 


\section{1. Појам и границе старости}

Изналажење реалне могућности за непрекидно трајање живота није ништа мање кобно од смрти, осим у предањима и веровањима, где натприродна бића своју бесмртност поткрепљују бројним преимућствима (Костић, 1997: 89). Пошто сенесценција почиње од рођења, парадоксално је да процес старења и старост као животно доба буду табу теме. „Сваки човек жели дуго да живи“, па самим тим „бити стар“ не треба да представља било какво посебно спорно питање. Али „нико не жели да остари“, па се старост међу становништвом већине држава света све више посматра као „социјални проблем“. ${ }^{1}$

Током развоја људског друштва људски век није увек трајао исто, већ се напротив продужавао, па се тренутак када неко улази у старачко доба одређивао по различитим критеријумима (број година, радна способност, физички изглед). Betty Friedan, у свом делу Fountain of Age, наводи да је само 8\% Американаца преко 65 година старости прихватило термин “стар”, да тиме опише себе. Скоро половина испитаника определила се за термине: “сениор грађанин”, “зрео Американац”, или “пензионисана особа”, као прихватљиве за опис свог статуса (Friedan, 2006).

У савременој медицинској литератури заступљено је мишљење да термине “старе особе” и “сениор грађани” треба дефинисати узимајући у обзир пре функционални статус, него хронолошке године, мада се из административних разлога старост особе изражава годинама (65 или 75 година). Такође, прави се подела ове групе на две подгрупе: “млађе-старије особе” (65-74 године) и на “стар-старије особе” (преко 85 година старости) (Krupp, 1988: 4).

Продужење трајања људског века значило је стално повећавање броја старих особа у односу на укупну популацију једне земље. У 20. веку, у односу на претходна раздобља, остварена је револуција у трајању људског живота. Просечно очекивано трајање људског века порасло је за 20 година до 1950. године, па је просечна старост тада достигла 66 година живота. Очекује се продужење трајања људског века за још 10 година до 2050. године. Овај демографски тријумф и брзи пораст популације у првој половини 21. века указује да ће број особа преко 60 година старости нарасти од око 600 ми-

1 “...промена која би водила ка корисном, активном и развојно оријентисаном погледу на старење може да произиђе из сопствених поступака старих људи, кроз саму снагу њиховог растућег броја, па самим тим и утицаја. Колективна свест о томе шта старење значи, у смислу концепта друштвеног изједначавања, може временом постати користан чинилац у промени става”. „Internetational Plan of Action on Ageing“, 1/para. 32, цит. у: Social Gerontology: „Old Age Across Cultures and Time“.

URL: http://www.trinity.edu/ mkearl/gercul.html, приступ: 13.10.2008. 
лиона у 2000. години на скоро 2.000 милиона у 2050. години. Процењено је да ће се пропорционална заступљеност особа, које су одређене као старе/ остареле, глобално повећати од $10 \%$ у 1998. години на $15 \%$ у 2025 . години.

Пораст броја старих становника биће највећи и најбржи у развијеним земљама света, и то у четвороструком износу за следећих 50 година. Тај ће пораст у најмањој мери бити забележен у земљама Африке (Madrid International Plan, 2002). Нешто прецизнији подаци указују на то да је педесетих година 20. века у САД живело 12.4 милиона мушкараца и жена старијих од 64 године, што је чинило 8,1\% од укупног броја становника. До 2004. године број старијих се утростручио, и порастао је на 36 милиона становника САД. Прогноза је да ће до средине 2030. године у САД живети преко 70 милиона старијих, што ће износити $25 \%$ од укупно пројектованог обима америчке популације тада (Eglit, 2004: 1).

У многим модерним индустријским друштвима досегнути старост као да подразумева припадање субординираној групи људи. Старији су често лимитирани у свом учешћу у друштвеном, економском и политичком животу, што онемогућава њихов довољни утицај у различитим сферама друштвеног живота, иако по броју они нису мањинска група. Већина улога у социјалној структури савремених друштава не припада старим особама, и за њих обитава само неколицина регуларних, санкцијом заштићених могућности за пуно учешће у друштвеном животу. Развија се један стални сукобљени однос између тежњи старих особа да им припадну одређене улоге у друштву, и тежњи млађег дела становништва да им те улоге не додели. Зато се положај старих људи може да пореди са положајем адолесцената. Наиме, њихове тешкоће да се прилагоде друштвеним захтевима су сличне. И међу једнима и међу другима често постоји осећање бескорисности, као и спознаја да њихове жеље скоро нико не спознаје. Садашњост је битна за радно способно становништво - стари људи из садашње перспективе немају будућност, а млади тек треба да ступе на њено тло.

У том смислу, живот старих особа често добија маргиналан карактер, као битисање људи који се налазе на рубу друштвеног живота. Утицај њихових свакодневних активности на токове друштвеног живота не може се, ни легалистичким оквиром, нити пак неким опште прихваћеним моралним нормама, дефинисати као доминантан у процесу доношења одлука, које би мењале стварност (Костић, Ђорђевић, 2004: 3).

\section{2. Делинквенција старијих}

Међутим, услед опадање физичке снаге и слабљења општег здравља, долази и до промена у социјалном положају старих особа у односу на 
онај који су имали као млађе особе. Старењем се губи иницијатива, опада радна способност и пре одласка у пензију (под условом да су уопште били запослени), старе особе бивају аутоматски искључене из низа активности које су судбоносне за њихову даљу егзистенцију.

У криминолошкој литератури се износи јасан став да је криминалитет старијих у непосредној вези с њиховим ступањем у нови период живота. Слично томе како неке младе особе, услед тешкоћа на које наилазе у првим фазама социјализације (детињство, младост) отпочињу своју делинквентну активност, тако и недостатност трећег доба живота, односно трећег периода социјализације, може утицати на појаву делинквенције код остарелих. Слично, или чак подударно као код младих, или млађих извршилаца кривичних дела, и код старијих делинквената могуће је уочити образац у развоју делинквентне активности, структуру криминалитета, полну заступљеност делинквентних лица, претходно кажњавање, као и друштвени статус остарелих делинквената (Hardtke, 1991).

И поред тога, остареле особе/стара лица дуго нису била предмет посебног криминолошког изучавања, ${ }^{2}$ у поређењу са темама расне или родне припадности, или сексуалне опредељености, које се доводе у однос криминогенезе, или виктимогенезе њиховог бивствовања. У криминолошкој књижевности отуда се истиче да је занимање за старије било најчешће у домену испитивања страха од криминалитета, или њихове виктимизације у оквиру породице, а да је њихова делинквенција много ређе била предмет изучавања. Опет, изучавање делинквенције старијих најчешће је било у значењу потреба и тешкоћа с којима је суочена затворска популација у трећем добу, када су изречене дугогодишње затворске казне, а правила условног отпуста остају строга, или када се критикује мањак посебних социјално прилагођених пенитенцијарних установа за остареле осуђенике. Такође, чак и када криминолози искажу интересовање за остареле учиниоце кривичних дела, њихова пажња усмерена је на старије као сексуалне делинквенте, док су друге категорије старијих извршилаца кривичних дела занемарене (Oxford, 2007: 160).

2 У криминолошкој теорији постоје три групе схватања које се односе на питање старости. По првој, најраспрострањенијој у криминологији, појам „старост“се користи као дескриптивна категорија. Друго, суштаствено, аналитичко одређење, потиче из теорије социјалне геронтологије, док је треће одређење везано за виктимолошки приступ старењу и старим особама. Видети: Rachel Pain, „Theorising Age in Criminology: the Case of Home Abuse", British Society of Criminology, The British Criminology Conferences: Selected Proceedings, Volume 2.http://www.britsoccrim.org/volume2/006.pdf, приступ: 25.11.2008. 
Према статистичким показатељима у САД, млађе особе се много учесталије јављају као извршиоци кривичних дела, у односу на пунолетне и оне старије. С друге стране, у областима САД у којима је сконцентрисанији живот већег броја старијих лица у односу на млађе, попут државе Флориде, њихова делинквенција уочава се као статистички значајна. На Флориди, проценат старијих лица која врше кривична дела расте брже од процента одраслих или млађих особа које почине неку делинквентну активност. Између 1980. и 1998. године, стопа сексуалних делинквената с Флориде у узрасту од 60 година и старијих порасла је за 171\%, док су разбојништва порасла за 168\%, а тешке телесне повреде за 13\%. Отуда изјава одговорног лица у Центру за обуку полиције на Флориди да полицајци „на своје огромно изненађење налазе себе како стављају лисице некоме ко је старији од 65 година (...), и да покушавају да их упозоре да то што су старији не значи и да су невини“. Ипак, на нивоу САД ниво криминалитета старијих није тако значајан. Током 2000. године, особе узраста од 65 година и старије учествовале су у укупном броју хапшења у САД са $0,6 \%$, а међу кривичним делима доминирале су крађе, попут џепарења, праћене тешким телесним повредама (Titus Reid, 2003: 41).

Међутим, анализом наведених података о дистрибуцији криминалитета на нивоу САД, учешће старијих у укупном криминалитету је веома ниско. Према подацима из Uniform Crime Reports, укупан број хапшења у САД, у 2012. години био је 9.446.660, или 100\%. Од тога, број хапшења старијих лица, за поједина кривична дела, или групе кривичних дела, био је заступљен на следећи начин: од 60 до 64 године - 118.772 хапшења или 1,3\%, а преко 65 година - 81.758 хапшења или 0,9\%. Дистрибуција криминалитета, према облицима испољених криминалних понашања, у извештају је представљена на следећи начин: убиство и умишљајно убиство: од 60 до 64 године 100, преко 65 година 93; силовање: од 60 до 64 године 200, преко 65 година 167; разбојништво: од 60 до 64 године 250, преко 65 година 108; тешке телесне повреде: од 60 до 64 године 4.059, преко 65 година 3.223; провалне крађе: од 60 до 64 године 1.011, преко 65 година 607; крађе: од 60 до 64 године 10.482, преко 65 година 7.757; крађе моторних возила: од 60 до 64 године 225, преко 65 година 118; паљевине: од 60 до 64 године 114, преко 65 година 73; други облици делинквентног понашања: од 60 до 64 године 10.631, преко 65 година 8.752; фалсификовања: од 60 до 64 године 428, преко 65 година 239; преваре: од 60 до 64 године 1.755, преко 65 година 1.323; проневере: од 60 до 64 године 141, преко 65 година 78; трговина украденом робом: од 60 до 64 године 430, преко 65 година 211; вандализам: од 60 до 64 године 1.177, преко 65 година 976; неовлашћено ношење оружја: од 60 до 64 године 1.094, преко 65 година 953; сексуална 
делинквенција: од 60 до 64 године 481, преко 65 година 371; злоупотреба опојних дрога: од 60 до 64 године 1.340, преко 65 година 1.622; коцкање: од 60 до 64 године 8.604, преко 65 година 3.651; насиље у породици: од 60 до 64 године 167, преко 65 година 156; вожња у пијаном стању: од 60 до 64 године 733, преко 65 година 510; злоупотреба алкохола: од 60 до 64 године 21.462, преко 65 година 15.403; пијанство: од 60 до 64 године 3.409, преко 65 година 1.851; преступи: од 60 до 64 године 8.497, преко 65 година 4.326; скитничење: од 60 до 64 године 5.290, преко 65 година 3.625. Посебно су издвојени случајеви хапшења лица од 60 до 64 године за криминалитет насиља 4.609 или $1,1 \%$, а за имовински криминалитет 11.832 или 0,9\%, и лица преко 65 година за криминалитет насиља 3.591 или $0,9 \%$, а за имовински криминалитет 8.555 или $0,7 \%$, у односу на укупан број хапшења (Uniform Crime Reports, 2012).

У приказаној анализи дистрибуције криминалитета по врсти кривичног дела и узрасту учинилаца, интересантно је да код свих облика испољених криминалних, односно делинквентних активности број хапшења старијих од 65 година опада у односу на старосну групу од 60 до 64 године. Изузетак је једино код злоупотреба опојних дрога, где је број хапшења порастао у узрасној групи од 65 година и старији.

Општи закључак је да ниво криминалитета опада с повећањем година старости. Овај феномен био је криминолошки објашњаван с различитих аспеката. Криминолози који су имали за предмет свог интересовања развитак криминалних каријера појединаца сматрају да нормални процеси биолошког и социопсихолошког сазревања смањују криминалну активност, а да старост омогућава људима да много исправније процењују вероватноћу успешности криминалног понашања. Многи делинквенти немају финансијске добитке током дугог периода времена, нити успевају да успешно избегну хапшење, осуду, нити упућивање у установе. Но, без обзира на различите објективне и субјективне околности, чини се да се „привлачност криминалитета битно смањује како криминалци постају старији“ (Titus Reid, 2003: 41).

У домаћој криминолошкој литератури, у деловима који се баве питањима криминалнефеноменологије, дистрибуција криминалитетапремастарости заокупља пажњу писаца у оној мери која се односи на стално растући обим малолетничке делинквенције, односно њено опадање, у односу на појаву сасвим нових облика криминалне активности међу младима. С друге стране, ово питање, ипак, налази своје место у литератури из области правне медицине, тачније судске психопатологије. Тако, Јевтић разматра питања форензичког значаја старосних душевних ненормалности, односно 
кривичну одговорност учинилаца у случају старосних психотичних стања. С обзиром на то да атеросклеротични душевни поремећаји и сенилна деменција доводе у питање подобност за урачунљивост, а самим тим и способност за расуђивање, деликтна понашања таквих особа, као изречене увреде, клевете, кривоклетства, ипак се отежано доказују због обичајног уважавања година, или поштовања према старијима. Јевтић код таквих особа посебно наглашава „интересовања за сва материјална питања“, затим тврдоглавост, педантерију, властољубље. Могуће је и младалачко еуфорично расположење, посебан начин облачења и понашања, који их често чини жртвама злоупотреба. Међутим, оно што их карактерише јесу и сексуални деликти, као „егзибиционизам или блудне радње и напаствовање девојчица, па и дечака“ (Jevtić, 1959: 351).

У криминолошкој литератури, поготову оној из англосаксонског говорног подручја, јасно се износе тврђења да је делинквенција старијих ипак постала предмет интересовања у криминологији, али тек од седамдесетих година прошлога века, када је и запажен енормни пораст броја ових становника у САД. Најраније студије из ове области предсказивале су да ће се у будућности старији све више упуштати у вршење кривичних дела, и да ће се тиме створити још један растући социјални проблем. Ове тврдње су поново разматране од стране криминолога осамдесетих година прошлог века, када је и доведена у питање валидност ове тврдње. Резултати обимних студија у САД су садржали исту тврдњу да криминалитет старијих никако не сме да буде окарактерисан као „геријатријски криминални талас“. Такође, закључено је да се повећава обим одређених облика криминалних понашања од стране старијих, с једне стране, док се, с друге стране, смањује обим неких других облика њихових делинквентних активности. Утврђено је да се повећава удео имовинског криминалитета, а да се смањује обим злочина без жртве, као што су: коцкање, опијање на јавном месту, скитничење и прекршаји против јавног реда и мира (Flynn, 2000: 47-48).

Интересантно је да чак ни у САД, све до 2000. године, када cy Max Rothman, Burton D. Dunlop и Pamela Entzel уредили монографију Elders, Crime, and the Criminal Justice System, није објављена ниједна опсежна студија која би се, искључиво или у највећој мери, бавила питањима учешћа, односно полажаја старијих у америчком кривичноправном систему.

\section{3. Пенитенцијарни третман старијих}

Доба живота остарелих, у свим својим ендогеним и егзогеним импликацијама, чини, на први поглед, виктимогеничним само њихово бивствовање. Представа о томе чак замагљује и њихову јасно видљиву позицију активних 
актера кривичног догађаја - дакле, у својству откривених извршилаца кривичних дела, односно у логичном следу догађаја, као осуђених лица.

За разлику од константног пораста удела старог становништва у односу на млађе становништво у развијеним земљама света, удео осуђеничке популације међу особама од 55 година живота и старијих, у односу на млађе осуђенике, ипак је знатно мањи. Наиме, према неким статистичким показатељима, током 1991. године, удео особа старости од 55 година и старијих међу извршиоцима кривичних дела у САД био је 2,9\%, у односу на укупан број извршилаца кривична дела. Током 1988. године, око 604.000 особа било је упућено у федералне и државне затворе на извршење казне затвора у САД. Од тог броја, око 20.000 били су старости од 55 година и старији. То значи да су тада око 3,3\% затвореничке популације чиниле особе од 55 година и старије, док је истовремено та старосна група бројала око 21,4\% укупне популације Американаца. Али, како је наглашено, због убрзаног пораста тог сегмента опште популације у САД (од 55 година и старији) сасвим је рационално да се очекује пораст удела остарелих особа и међу осуђеничком популацијом (Elderly Persons in Prison).

Ова очекивања, из визуре данашњице, нашла су своју потврду. Наиме, различита питања која се односе на „старе особе иза решетака“ постала су, временом, предмет интересовања, не само криминолога и пенолога, или државне администрације, већ и међународних организација које се залажу за примену људских права. Нека њихова истраживања, за разлику од опште увреженог мишљења, полазе од претпоставке да нема разлике између старијих и млађих осуђеника, и да су осуђеници од седамдесет и пет година старости, активнији, независнији и здравији од оних много млађег узраста. Међутим, услед биолошког старења организма, код њих се много чешће јављају хроничне болести и стална погоршања здравља. Стога, у казненопоправном систему САД развиле су се посебне хронолошке старосне групе осуђеника, које служе да затворској администрацији укажу на физичке и менталне промене и стања здравља, које карактеришу процес старења организма. Због тога, у многим савезним државама САД та доња граница у класификовању затворске популације износи педесет година, а горња седамдесет, док се у социјалном окружењу, на слободи, особе узраста од 50 до 55 година не могу сматрати остарелима. Утамничени мушкарци и жене уобичајено пате од физичких и психичких потешкоћа које карактеришу особе на слободи, али бар десетак година старије. Насиље, анксиозност, стрес у затворским условима, одвојеност од породице и пријатеља, као и спознаја могућности да ће сав или скоро сав остатак живота провести иза решетака, све заједно могу довести до убрзаног процеса старења код осуђених лица. 
У САД се примећује чак драматичан пораст броја осуђених лица изнад 65 година старости. У 2007. години њих је било 16.200, а у 2010. години већ 26.200 , или за $63 \%$ више. Током тог истог периода, укупан број осуђених лица био је повећан за 0,7\%. У периоду 1995-2010. године, био је примећен видљив пораст броја осуђених старијих, с тим што су у статистикама издвојене особе од 55 година и старије, и оне до 55 година. Током 1995. године, у САД затворска популација је бројала 1.085 .369 осуђеника, од тога 32.600 старијих од 55 година, а у 2010. години 1.543 .206 осуђеника, а од тога 124.400 старијих од 55 година. Број осуђених лица старијих од 55 година растао је много брже од раста укупне затворске популације, за $282 \%$, у односу на $42,1 \%$ повећања затворске популације уопште (Human Rights Watch: Old Priosners, 2012).

Као узрок за повећање удела старијих међу затворском популацијом у САД, у литератури се наводе: дужевременске казне затвора; доживотне казне затвора; повећање удела старијих извршилаца међу ухапшенима; недостатак легалних услова за ранији отпуст (Human Rights Watch: Why the Aging Prison Population, 2012).

Затворске зграде, правила и обичаји у неформалном систему стварају се тако да су прилагођени потребама и стилу живљења млађих осуђеника. Рад на удаљеним местима, степениште или стајање у реду приликом прозивке некада представљају немогуће услове боравка за старије осуђенике. Инконтиненција и деменција код старијих стварају нове потешкоће, али и неопходност другачијег прилагођавања затворског особља у поступању са старијим осуђеницима, па стога „затворско особље које ради са старијима зна да нема смисла викати на осуђеника који не разуме шта му се говори“ (Human Rights Watch: Conditions of Confinement, 2012).

Резултати научних студија указују да се јасно издвајају три категорије старијих осуђеника. Прву групу чине они који су осуђени на дуге временске казне затвора које су им изречене још у младости, за примарни насилни злочин који су извршили, и који су остарили у затвору. Они се, најчешће, добро прилагођавају условима живота у затвору, и често служе за узор другима. Међутим, дугачки период институционализације, мањак социјалних веза и ограниченост у радном искуству утичу да се ова група суочава с највећим тешкоћама у социјалној реинтеграцији по отпусту.

Другу групу чине делинквенти из навике, који су током целог свог живота између неслободе, односно повратници. Они се рационално прилагођавају животу у затвору, често пате од хроничних здравствених проблема, укључујући и историју злоупотребе опојних дрога. Друштвене везе су им лимитиране, а прошлост радног искуства спорадична. 
Трећу групу чине они који су били осуђени због тешких облика криминалитета у каснијем периоду живота. Најтеже се прилагођавају условима живота у затвору и најчешће су у ситуацији да буду виктимизирани од стране других осуђеника. Највећи број њих су сексуални делинквенти.

За све три групе осуђених лица треба обезбедити различите програме који ће задовољити њихове потребе. Појединачно, сваки од осуђеника има различите здравствене потешкоће, неки облик зависности, или физичку или психичку неспособност, према чему се морају одредити различити програми поступања, којима ће се задовољити појединачни субјективни и објективни интереси осуђених лица (UNODC, 2009: 126).

Различити приступи у истраживањима старијих осуђеника баве се и различитим питањима, као: лични профили осуђеника; социјалнопсихолошке последице затворског окружења; једнакост у односима осуђеника и статусна хијерархија; учешће у основним социјалним институцијама; конформизам у затворским правилима, као и условни отпуст. Свакако да томе треба придодати и питања увођења специјализованих програма и поступака, као и олакшица за старије осуђенике (Goetting, 1983).

Међународне организације, као Уједињене нације, баве се посебним потребама и изазовима боравка старијих осуђеника у затворима. Ту се, пре свега, изучавају: приступ правди; вршење процена; смештај; здравствена нега; породичне везе; затворски програми; припреме за отпуст и постпенална подршка; ранији условни отпуст; мултипликованост њихових потреба. Изучавају се међународни стандарди везани за кажњавање и затварање старијих делинквената, као и одговори на потребе њиховог боравка у установама (казнена политика; ванинституционалне кривичне санкције; формални систем) (UNODC, 2009: 123).

\section{4. Закључна разматрања}

Код старијих осуђеника уочава се низ сличних потреба које морају да задовоље у личном и друштвеном животу на слободи, и свих последица које из тога проистичу (здравствена нега и трошкови лечења, на пример), ${ }^{3}$

3 Тешкоће које се јављају упућивањем остарелих осуђеника на извршење затворских казни могу се, уопштено посматрано, сврстати у две категорије. Једна обухвата здравствена и социјална питања која непосредно погађају остареле осуђенике, док друга обухвата финансијске тешкоће у односу на оптерећење здравствених фондова за лечење и заштиту остарелих осуђеника, као и административне тешкоће у односу на бригу и заштиту остарелих осуђеника. Видети: „Elderly Felons: A Research Proposal“, http://www.lotsofessays.com/viewpaper/1706293.html, приступ: 17.12.2009. 
па се предлаже низ мера које би, најпре, ублажиле тешкоће у периоду њиховог утамничења у поправним домовима и затворима (на пример, трошкови за државу, одсуство породице која би се о томе старала и сл.), као и у припремама за отпуст. Тако, могуће је указати на неке алтернативне корективне мере за остареле осуђенике. Захтев који мора бити задовољен и у овом случају односи се на добробит и друштва и остарелих осуђеника. Зато је потребно спојити, уједначити и испољавати извесне ставове у кривичном правосуђу, попут: смањивања броја институционалних мера; повећања обима олакшица условног отпуста за њих; закључивање приватних уговора у вези с посебним олакшицама за остареле осуђенике који треба да буду условно отпуштени из безбедносних разлога; као и установљавање болничких одељења у заводима за остареле осуђенике који су на самрти. ${ }^{4}$

Закон о извршењу кривичних санкција Републике Србије ${ }^{5}$ не регулише посебним одредбама положај старих осуђеника. У оквиру општих одредби о забрани дискриминације, забрањује се стављање у неравноправан положај лица према коме се извршава кривична санкција, због расе, боје коже, пола, језика, вере, политичког и другог уверења, националног или социјалног порекла, имовног стања, образовања, друштвеног положаја или другог личног својства (члан 7). У члану 24. став 4. предвиђено је да завод мора располагати посебном просторијом за издвајање оболелих осуђених, у зависности од природе обољења. ${ }^{6}$

Законописац још у једној одредби експлиците помиње године живота осуђеника, и то када регулише права осуђеног лица, односно слободно време осуђеног. Наиме, у чл. 80 је предвиђено да осуђени има право да изван затворених просторија на свежем ваздуху, у слободно време, проведе најмање два часа дневно. Осуђени, коме године и телесне способности то дозвољавају, има право у слободно време на организовану физичку активност, укључујући и право да заједно с другим осуђеницима користи спортске терене и опрему.

Узраст осуђених лица у Закону о извршењу кривичних санкција се предвиђа као посебан критеријум у одредбама о смештају осуђеника. Приликом регулисања смештаја, предвиђено је да се разврставање

4 "Alternative Corrections Policies for Elderly Felons“, http://www.lotsofessays.com/ viewpaper/1687838.html, приступ: 17.12.2009.

5 Закон о извршењу кривичних санкција Републике Србије „Сл. гласник РС“, бр. 55/2014

6 Оболевање од тешке, неизлечиве болести, што наравно не мора бити увек повезано са остарелошћу осуђеника, може бити наведена као околност која се узима као оправдана за давање помиловања код нас. (Миладиновић, 2006:145) 
осуђеног у просторије за заједнички боравак и спаваонице спроводи уз брижљиву оцену свих околности и података евидентираних у пријемном одељењу, посебно имајући у виду узраст, личне особине и склоности, као и друга својства од којих зависи позитиван међусобни утицај и непостојање опасности од међусобног физичког и психичког угрожавања. Осуђени с инвалидитетом има право на смештај примерен врсти и степену његових посебних потреба (чл. 77).

У нашој земљи донет је Закон о потврђивању Конвенције о трансферу осуђених лица са Додатним протоколом. ${ }^{7}$ На основу ове Конвенције, до трансфера може доћи само под одређеним условима, међу којима је и онај који се односи на старост осуђеног лица. Тако је у чл. 3 прописано да када због година старости, менталног или физичког стања једна од држава сматра неопходним, осуђено лице или његов представник морају дати сагласност за трансфер.

У средствима јавног информисања налази се податак да је за Србију карактеристичан превелики број осуђених лица у заводима, у односу на предвиђене капацитете, чак највећи од свих 47 земаља чланица Савета Европе. Статистички подаци за 2012. годину показују да је у Србији на 100 прописаних места у заводима смештено 160 затвореника. После Србије следи Италија са 140 затовереника на 100 места, затим Кипар са 140, Мађарска са 139 и Белгија са 132 затвореника на 100 места (Срспки затвори пребукирани, 2014).

Процењено је да је током 2008. године у српским затворима било преко 150 осуђеника старости преко 70 година (Српска православна црква, 2008). Прецизне статистичке показатеље износи Управа за извршење заводских санкција. Наиме, према Годишњем извештају о раду Управе за 2009. годину, од укупног броја примљених лица, 9.023, узраст осуђених старијих лица примљених у тој години био је следећи: лица од 50 до 60 година - 789; од 60 до 70 година 245; и, од 70 година и више - 66. Процентуално, они су чинили $0,12 \%$ од укупно примељене осуђеничке популације (Управа за извршење кривичних санкција, 2009). Тај број унеколико је био мањи у 2010. години, али процентуално идентичан. Од укупног броја примљених лица, 7.660, узраст осуђених старијих лица примљених у тој години био је следећи: лица од 50 до 60 година - 692; од 60 до 70 година 224; и, од 70 година и више - 40 (Управа за извршење кривичних санкција, 2010: 71). У 2011. години, као и у 2010. години, скоро истоветан број старијих лица

7 Закон о потврђивању Конвенције о трансферу осуђених лища са Додатним протоколом. „Службени лист СРј“ - Међународни уговори, број 4/01.

http://www.tuzilastvorz.org.rs/html_trz/PROPISI_KONVENCIJE/konvencija_transfer_cyr. pdf приступ: 9.2.2010. 
био је примљен у заводе. Од укупног броја примљених лица, 7.925, узраст осуђених старијих лица примљених у тој години био је следећи: лица од 50 до 60 година - 687; од 60 до 70 година 199; и, од 70 година и више - 50 (Управа за извршење кривичних санкција, 2011: 113), или, процентуално $0,11 \%$.

Осим промене терминологије од 2011. године, када Управа отпочиње да статистички евидентира лица по старости, а не више по узрасту, у 2012. години начињен је још један помак. Наиме, структуралним показатељима евидентираних по старости примљених осуђених, сада се придодаје и разврставање по полу, код свих старосних категорија. Тако је у 2012. години било примљено 7.962 мушкарца и 318 жена, укупно посматрано. Од тога, узраст и пол осуђених старијих лица примљених у тој години био је следећи: лица од 50 до 60 година - 750, и то 703 мушкарца и 47 жена; од 60 до 70 година 260, и то 247 мушкараца и 13 жена; и, од 70 година и више - 54, и то 52 мушкарца и 2 жене (Управа за извршење кривичних санкција, 2012: 95). У 2013. години било је примљено 7.074 мушкарца и 295 жена, укупно посматрано. Од тога, узраст и пол осуђених старијих лица примљених у тој години био је следећи: лица од 50 до 60 година - 766, и то 725 мушкарца и 41 жена; од 60 до 70 година 242, и то 229 мушкараца и 13 жена; и, од 70 година и више - 44, и то 41 мушкарац и 3 жене (Управа за извршење кривичних санкција, 2013: 112).

У посматраном периоду могуће је уочити скоро непромењен број, односно проценат заступљености, старијих осуђеника у укупној затворској популацији у Србији. Тај број можда не изгледа као растући, као у неким развијеним земљама света, али, опет, представља невидљиви део слике осуђеничке популације у Србији. Оно што је слично условима живота на слободи, да су старији маргинализовани у односу на радно способно становништво, одражава се, попут рефлексије, и у затворским условима. Не постоје законске, нити било какве друге препреке, да се део научног сазнања наставника и сарадника правних факултета, на којима се изучавају криминологија, пенологија и виктимологија, примени у пракси, ради побољшања ефикасности примене криминалнополитичких мера, као ретрибутивних и превентивних процеса и поступака у борби против криминалитета (Јовашевић, Костић, 2012).

Примери добре праксе, преузети из упоредноправне литературе, могу послужити као узор за стварање сопствених програма. Пројекат за старије осуђенике је назив програма основаног 1989. године у САД. Овај програм је предвиђен као вид спречавања појаве превеликог броја осуђених лица у затворима, и намењен је старијим осуђеницима и онима 
који су у неповољнијем положају (болесни, странци). Од установљења, на програму је учествовало више од 500 осуђених лица и тврди се да је утицао на истраживање легислативне рефоме на нивоу савезне државе, као и појединих држава (Abner, 2006: 11).

Институт за кривично правосуђе САД је још 2001. године установио да је петнаест од четрдесет и четири државе и територија појединих држава обезбедило надгледане рекреативне програме посебно осмишљене за старије и остареле осуђенике. Друге државе увеле су образовне програме за побољшање здравља и о питањима старења као део превентивних заштитних програма, уопште. У Охају развијени су програми за осуђенике старије од педесет година који се односе на њихове физичке, психичке и социјалне потребе. Осмишљене су рекреативне вежбе, основно образовање за одрасле, као и одговарајуће друштвене игре (бинго, организоване шетње). Друге државе, попут Пенсилваније, на пример, обезбеђују медицинске едукативне програме, којима нуде едукацију о здравој исхрани и о смањењу телесне тежине. Приметна је и распрострањеност покрета који се залаже за обезбеђење посебних смештајних капацитета за старије осуђенике, од којих се у некима примењује потребна здравствена нега (Abner, 2006:10).

Питање малог броја старијих и остарелих осуђеника код нас не сме да буде разлог за непоступање, односно опредељење према овој појави. Стицање праксе студената права, медицине, психологије, физичке културе може да буде само део интересовања у образовном систему државе за бољу едукацију будућих стручњака. Развијање емпатије према потребама других, у условима јасно примењене ретрибутивне правде, као и мењање свести грађана о предностима ресторативног приступа, неће умањити остварење принципа легалитета. Објективност државног приступа је довољна само на нивоу буџетских уштеда, али уз обезбеђење законских норми и адекватног политичког приступа решавању питања превеликог броја осуђених лица у затворима, као и оних осуђеника који имају посебне физичке, психичке и социјалне потребе (старији, оболели, странци).

\section{Литература}

Abner, C. (2006). Graying Prisons - States Face Challanges of an Aging Inmate Population. Retrieved 5, September 2014, from: http://www.csg.org/knowledgecenter/docs/sn0611GrayingPrisons.pdf

„Alternative Corrections Policies for Elderly Felons“, http://www.lotsofessays. com/viewpaper/1687838.html, приступ: 17.12.2009. 
Eglit, H. (2004). Age and Ageism in the American Legal System. The University Prss of Florida.

„Elderly Persons in Prison“, http://www.lotsofessays.com/viewpaper/1699988. html, приступ: 17.12.2009. У: Костић, М. (2010). Виктимитет старих људи. Ниш: Правни факултет. (59).

„Elderly Felons: A Research Proposal“, http://www.lotsofessays.com/viewpaper/1706293.html, приступ: 17.12.2009. У: Костић, М. (2010). Виктимитет старих људи. Ниш: Правни факултет. (59).

Flynn, E. (2000). Elders as Perpetrators. In: Elders, Crime, and the Criminal Justice System. (Ed. by Max Rothman, Burton D. Dunlop, Pamela Entzel). Retrieved 5, September 2014, from http://books.google.rs/books?id=6mGG7eyFmjQC\&p $\mathrm{g}=$ PA43\&lpg=PA43\&dq=Flynn,+Elders

Friedan, B. (2006) The Fountain of Age. U: Social Gerontology: "Social Psychology of Aging", http://www.trinity.edu/cmkearl/gersopsy.html, приступ: 13.10.2008.

Goetting, A. (1983). The Elderly in Prison: Issues and Perspectives. Jouranl of Research in Crime and Delinquency. 20: 291-309.Retrieved 5, September 2014, from http://jrc.sagepub.com/content/20/2/291.abstract

Hardtke, F. (1991). Criminal acts by the elderly. A phenomenologic presentation with discussion of criminologic and gerontologic explanatory approaches, Arch Kriminol. 1991 Jul-Aug;188(1-2):1-19. Retrieved 23, August 2014, from http:// www.ncbi.nlm.nih.gov/pubmed?term=Hardtke\%20F\%5BAuthor\%5D\&cautho r=true\&cauthor_uid=1953243

Human Rights Watch. Old Behind Bars: Older Prisoners. (2012). Retrieved 5, September 2014, from http://www.hrw.org/node/104747/section/

Human Rights Watch: Old Behind Bars: Why the Aging Prison Population. (2012). Retrieved 8, September 2014, from hhttp://www.hrw.org/ru/node/104747/ section/6

Human Rights Watch: Conditions of Confinement. (2012). Retrieved 9, September 2014, from http://www.hrw.org/ru/node/104747/section/7

Jevtić, D. (1959) Sudska psihopatologija. Beograd, Zagreb: Medicinska knjiga.

Јовашевић, Д., Костић, М. (2012). Политика сузбијања криминалитета. Ниш: Центар за публикације.

Костић, М. (2010). Виктимитет старих људи. Ниш: Правни факултет.

Костић, М., Ђорђевић, Р., (2004). Виктимизација старих особа као припадника посебне маргиналне групе. Београд: Темида. (7). 3-11. 
Костић, М. (1997). Старост као доба живота и ризик виктимизације. Београд: Социјална мисао. (Април-јуни, 02). 89-98.

Krupp, A.M. (1988). Интерна медицина. Београд: Савремена администрација. Madrid International Plan on Action on Ageing 2002, 12 April 2002 www.un.org/esa/socdev/ageing/madrid_intlplanaction.html, npucmyn: 30.11.2007. Миладиновић, Д. (2006). Осврт на концепт помиловања у кривичном законодавству Србије. Зборник Правног факултета у Нишу. (XLVI). 133-150.

Министарство правде Републике Србије. Управа за извршење кривичних санкција. (2009). Годишњи извештај о раду Управе за извршење кривичних санкција за 2009. годину. Приступ: 10.9.2014. Ca: http://www.uiks.mpravde. gov.rs/images/izvestaj\%202009.pdf

Министарство правде Републике Србије. Управа за извршење кривичних санкција. (2010). Извештај о раду управе за 2010. годину. Приступ: 10.9.2014. Ca: Godisnji\%20izvestaj\%20o\%20radu\%202010[1].zip - ZIP archive, unpacked size 3.247 .025 bytes

Министарство правде Републике Србије. Управа за извршење кривичних санкција. (2011). Извештај о раду Управе за извршење кривичних санкција за 2011. годину. Приступ: 10.9.2014. Ca: http://www.uiks.mpravde.gov.rs/images/ Godisnji_2011_\%20UIKS.pdf

Министарство правде Републике Србије. Управа за извршење кривичних санкција. (2012). Извештај о раду Управе за извршење кривичних санкција за 2012. годину. Приступ: 10.9.2014. Ca: hhttp://www.uiks.mpravde.gov.rs/ images/UKKS_izvestaj_2012.pdf

Министарство правде Републике Србије. Управа за извршење кривичних санкција. (2013). Годишњи извештај о раду Управе за извршење кривичних санкција за 2013. годину. Приступ: 10.9.2014. Ca: http://www.uiks.mpravde. gov.rs/images/Godisnji_izvestaj_UIKS-a_za_2013.pdf

The Oxford Handbook of Criminology, (2007) (ed. by: Mike Maguire, Rod Morgan, and Robert nReiner). Oxford Univerzity Press.

Rachel Pain, „Theorising Age in Criminology: the Case of Home Abuse“, British Society of Criminology, The British Criminology Conferences: Selected Proceedings, Volume 2.

Српскизатворипребукирани.(2014).Уторак 29.април 2014,приступ:12.9.2014. ca: http://www.rts.rs/page/stories/sr/story/125/Dru\%C5\%A1tvo/1586252/ Srpski+zatvori+prebukirani.html 
Српска православна црква. (2008) „Српски затвори пребукирани“.

http://www.spc.rs/sr/srpski_zatvori_prebukirani, приступ: 9.2.2010. У: Костић, М. (2010). Виктимитет старих људи. (стр. 58-61). Ниш: Правни факултет.

Social Gerontology: „Old Age Across Cultures and Time“,

„Internetational Plan of Action on Ageing", 1/para. 32, http://www.trinity. edu/ mkearl/gercul.html, приступ: 13.10.2008.

Titus Reid, S. (2003) Crime and Criminology, New York: McGrawHill.

Uniform Crime Reports, Crime in the United States 2012. Retrieved 23, August 2014, from http://www.fbi.gov/about-us/cjis/ucr/crime-in-the-u.s/2012/crimein-the-u.s.-2012/tables/38tabledatadecoverviewpdf

UNODC: Handbook on Prisoners with special needs. (2009). New York: United Nations. Retrieved 10, Septembert 2014, fromhttp://www.unodc.org/pdf/criminal_justice/Handbook_on_Prisoners_with_Special_Needs.pdf

Закон о извршењу кривичних санкција Републике Србије, „Сл. гласник РС“, бр. 55/2014.

Закон о потврђивању Конвенције о трансферу осуђених лица са Додатним протоколом, „Службени лист СРЈ“ - Међународни уговори, број 4/01,

http://www.britsoccrim.org/volume2/006.pdf, приступ: 25.11.2008. У: Костић, М. (2010). Виктимитет старих људи. Ниш: Правни факултет. (стр. 15).

http://www.tuzilastvorz.org.rs/html_trz/PROPISI_KONVENCIJE/konvencija_transfer_cyr.pdf приступ: 12.9.2014. 
Miomira Kostić, LL.D.

Full Professor,

Faculty of Law, University of Niš

\section{Elder Inmates}

\section{Summary}

The criminological literature underscores that criminal offences committed by senior citizens are directly related to their age and entering a new stage of life. In elder offenders, we may observe a distinctive pattern in the development of their criminal activities, the structure of crime, gender-specific criminal offences, their previous criminal records and their social status. The former criminological studies on the elderly population have most frequently focused on examining the senior citizens' fear of crime and their victimization within the family; the studies on criminal offences committed by the elderly seem to be rather scarce. The prior research into the criminal activity of elder offenders has largely addressed the needs and difficulties encountered by elderly inmates, particularly in case they were sentenced to long-term imprisonment and subject to strict parole rules. Some researchers have also extended criticism on the lack of special correctional facilities specifically designed for elder inmates.

In general, crime rate drops with aging. In developed countries, there is a constant increase of elder population as opposed to the marked decrease of younger population. Yet, the percentage of convicted offenders among the persons over the age of 55 is still significantly lesser as compared to the percentage of younger convicts. Namely, different issues pertaining to "elder people behind bars" have eventually become the subject matter of interest of criminologists and penologists, public administration authorities and international organizations advocating the observance of human rights. The incarcerated men and women face many physical and psychological problems which are generally encountered by all people at large but usually at a later age, when they are at least 10 years older than the inmates. Violence, anxiety and distress caused by the immediate prison environment, separation from their friends and families, and the awareness that they are most likely to spend the rest or most of their lives in prison may altogether accelerate the aging process in elderly inmates.

Key words: aging, elder inmates, elder delinquency, treatment of elderly offenders. 